\title{
Physical, Chemical and Physiological Properties of Difructose Anhydride III Produced from Inulin by Enzymatic Reaction
}

\author{
(Received December 8, 2003 ; Accepted May 27, 2004)
}

\author{
Hiroto Kikuchi, ${ }^{1, *}$ Taizo Nagura, ${ }^{1}$ Masanao Inoue, ${ }^{1, * *}$ Taro Kishida, ${ }^{1, * * *}$ Hiroaki Sakurai, ${ }^{1}$ Atsushi Yokota, ${ }^{2}$ \\ Kouzou Asano, ${ }^{2}$ Fusao Tomita, ${ }^{2}$ Kouji Sayama' and Yoshihiro Senba' \\ ${ }^{1}$ Research Center, Nippon Beet Sugar Mfg. Co., Ltd. (9-13, Inada-cho, Obihiro 080-0831, Japan) \\ ${ }^{2}$ Department of Applied Bioscience, Graduate School of Agriculture, Hokkaido University \\ (Kita-9, Nishi-9, Kita-ku, Sapporo 060-8589, Japan)
}

\begin{abstract}
We produced high purity difructose anhydride III (DFA III; $\alpha$-D-fructofuranose- $\beta$-D-fructofuranose $1,2^{\prime}: 3^{\prime}, 2$ dianhydride) crystals from the crude inulin extracted from chicory with inulin fructotransferase (depolymerizing) induced by H65-7 strain of Arthrobacter sp. The physical, chemical, and physiological properties of DFA III have been investigated in this report. The degradability and Maillard reactivity of DFA III in the low pH solutions were much lower than those of sucrose. DFA III showed no utilization by Streptococcus mutans and Bifidobacterium in vitro. Digestion test with rat intestinal acetone powder and absorption test with everted sacs of rat small intestine showed that DFA III had low digestibility and absorbability in vitro. Diet containing $2 \%(w / w)$ DFA III increased the cecal short chain fatty acids and induced a shift of the cecal microflora in rats. On the other hand, a daily oral ingestion of $5 \mathrm{~g}$ DFA III by healthy adults showed no influence on fecal microflora.
\end{abstract}

Key words: difructose anhydride III, oligosaccharides, inulin, prebiotics, intestinal microflora

Chicory (Cichorium intybus L.) is a perennial plant and is widely cultivated in Europe. Its leaves are used in salads, and its roots are used as the raw material for a coffee substitute. Chicory roots also contain a large amount of inulin that is a linear $\beta$-2,1-linked fructan with sucrose residue. Inulin has been utilized as a water-soluble dietary fiber and a substitute for fat.

Producing oligosaccharides from inulin by hydrolyzation has been attempted. For example, fructooligosaccharide has been produced from inulin by hydrolyzation. The enzymes producing difructose anhydride III (DFA III, Fig. 1), inulin fructotransferase (depolymerizing), have also been detected in several kinds of microorganisms. ${ }^{1-3)}$ High purity DFA III crystals were efficiently produced from the crude inulin extracted from chicory by enzymatic reaction (Kikuchi, H. et al., unpublished data). Inulin fructotransferase (depolymerizing) induced by the H65-7 strain of Arthrobacter sp. ${ }^{4}$ was used for the production of DFA III.

Oligosaccharides are known to have functions that favorably influence the indigenous intestinal microflora in terms of microbial balance, and thereby, help in improving our health. ${ }^{5}$ This concept is called "prebiotics." Stimulation of calcium absorption in the large intestine is also

${ }^{*}$ Corresponding author $($ Tel. $+81-155-48-4106$, Fax. $+81-155-$ 47-0711, E-mail: kikuti@nitten.co.jp).

** Present address: Memuro Factory, Nippon Beet Sugar Mfg. Co., Ltd. (26, Higashi-Memuro Ki-sen, Memuro-cho 082-0005, Japan).

*** Present address: Department of Biological Resources, Faculty of Agriculture, Ehime University (3-5-7, Tarumi, Matsuyama 790-8566, Japan).

Abbreviations: DFA III, difructose anhydride III; PBS, phosphate buffer saline. one of the notable functions of oligosaccharides. ${ }^{6,7)}$ Though reports suggested that DFA III efficiently stimulates calcium absorption not only in the large intestine but also in the small intestine, ${ }^{8,9)}$ there are no reports to confirm the properties of DFA III in detail. In this paper, we report the physical, chemical, and physiological properties of DFA III.

\section{MATERIALS AND METHODS}

Chemicals. Chicory that contains a large amount of inulin in its root was cultivated on a farm located in Hokkaido, Japan. Inulin was extracted from the harvested chicory roots with hot water. The carbonation juice was obtained from the extract by refining it with the standard liming and carbonation technology of beet sugar factories. DFA III was prepared from the carbonation juice containing $15 \mathrm{~kg}$ of inulin with $110,000 \mathrm{U}$ of inulin fructotransferase (depolymerizing) that was induced by Arthrobacter sp. H65-7 at $58^{\circ} \mathrm{C}$ for $24 \mathrm{~h}$. The amount of DFA III was $9.8 \mathrm{~kg}$ in the reaction mixture. The mixture was refined with yeast fermentation and ion exchange resin. DFA III crystals $(3.0 \mathrm{~kg})$ were crystallized from the refined solution. The purity of the DFA III crystals was $99.7 \%$. The purities of sucrose and raffinose (Nippon Beet Sugar Mfg. Co., Ltd., Tokyo, Japan) were 99.9 and $99.5 \%$ respectively. Sorbitol, palatinose, xylitol and fructooligosaccharide were purchased from Wako Pure Chemical Industry (Osaka, Japan).

Animals and diets. Male Sprague-Dawley (SD) rats purchased from Japan SLC (Shizuoka, Japan) were used in the everted sac experiment and animal experiment. The rats were individually housed in stainless steel cages with mesh bottoms at $22 \pm 2^{\circ} \mathrm{C}$ under a 12 : 12-h light: dark 

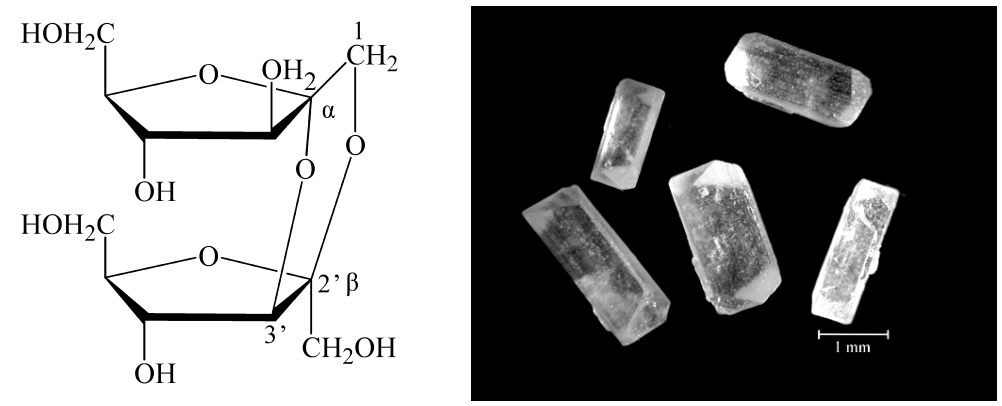

Fig. 1. The structural formula and crystals of difructose anhydride III.

photoperiod, and were allowed free access to the basal or experimental diets and tap water. The purified basal diet was composed of $23 \%(\mathrm{w} / \mathrm{w})$ casein, $61.4 \%$ corn starch, $5 \%$ cellulose, $5 \%$ corn oil, $4 \%$ mineral mixture (mixture $\left.2^{10)}\right), 1 \%$ vitamin mixture (AIN-76 ${ }^{11)}$ ), $0.3 \%$ DL-methionine, $0.2 \%$ choline chloride and $0.1 \%$ vitamin E. Experimental diets were prepared by replacing corn starch from the basal diet by adding DFA III at $2.0 \%(\mathrm{w} / \mathrm{w})$ or raffinose at $5.0 \%$. This study was approved by the Hokkaido University Animal Committee, and animals were maintained in accordance with the Hokkaido University guidelines for the care and use of laboratory animals.

Determination of saccharides. Saccharides were determined by high performance liquid chromatography (HPLC) with a refractive index detector (eluent, water; flow rate, 0.5-1.0 $\mathrm{mL} / \mathrm{min}$; column temperature, $80^{\circ} \mathrm{C}$; columns, SUGAR KS-801 or SP0810, $8 \times 300$ mm, Showa Denko K.K., Tokyo, Japan).

Investigation of physical and chemical properties.

(1) Moisture. Moisture of DFA III was calculated from the change in weight during heating at $105^{\circ} \mathrm{C}$ for $5 \mathrm{~h}$.

(2) Sweetness. The subjects chose a solution from the sucrose solutions of variable concentrations, which was equivalent to the sweetness of $12 \%(\mathrm{w} / \mathrm{v})$ solution and $16 \%(\mathrm{w} / \mathrm{v})$ solution of DFA III, respectively. The temperature of the solutions was maintained at $20^{\circ} \mathrm{C}$. For example, if the sweetness of $6 \%(\mathrm{w} / \mathrm{v})$ solution of sucrose is equivalent to the sweetness of $12 \%(\mathrm{w} / \mathrm{v})$ solution of DFA III, the sweetness of DFA III will be evaluated as $50 \%$.

(3) Melting point. The melting point was measured by a melting point instrument (FP62, Mettler-Toledo International Inc., Greifensee, Switzerland).

(4) Optical rotation. The optical rotation was measured by an automatic sugar polarimeter (Sucromat, Dr. Wolfgang Kernchen GmbH, Seelze, Germany).

(5) Solubility. The suspension of DFA III or sucrose was stirred at various temperatures over $1 \mathrm{~h}$. The concentration ( $\mathrm{g} / 100 \mathrm{~g}$ water) of supernatant (saturated solution) was determined by a Brix scale (RX-1000, Atago Co., Ltd., Tokyo, Japan).

(6) Viscosity. Viscosity of the solution containing DFA III or sucrose at $40 \%(\mathrm{w} / \mathrm{w})$ was measured by a viscometer at $24-70^{\circ} \mathrm{C}$.

(7) Hygroscopicity. DFA III and sucrose were placed under relative humidity of 75 or $94 \%$. The moisture of each saccharide was calculated from the change in weight at a definite time. Humidity for each saccharide sample was obtained from a closed glass case containing the satu- rated sodium chloride solution (relative humidity, $75 \%$ ) or the saturated potassium nitrate solution (relative humidity, $94 \%$ ), which were incubated at $20^{\circ} \mathrm{C}$.

(8) Degradability under acidic and heated conditions. Hydrochloric acid was used to adjust the $\mathrm{pH}$ of $1 \%$ (w/ v) DFA III or sucrose solution from 1 to 5 . The solutions were incubated at $100^{\circ} \mathrm{C}$ for $30 \mathrm{~min}$. Undegraded saccharides were determined by HPLC.

(9) Degradability under acidic conditions for a long term. Citric buffer solution (100 mM, pH 3) containing $12 \%(\mathrm{w} / \mathrm{v})$ DFA III or sucrose was filtrated, and then incubated at $37^{\circ} \mathrm{C}$ for 3 months. Undegraded saccharides were determined by HPLC.

(10) Maillard reactivity. The Sørensen phosphate buffer solution (200 mM, pH 3.3-7.4) containing $10 \%(\mathrm{w} / \mathrm{v})$ DFA III or sucrose and $1 \%(\mathrm{w} / \mathrm{v})$ glutamic acid was incubated at $120^{\circ} \mathrm{C}$ for $2 \mathrm{~h}$. The coloring by the Maillard reaction was evaluated from the absorption value at $420 \mathrm{~nm}$.

\section{Investigation of physiological properties.}

(1) Cariogenic test. One loopful of the Streptococcus mutans 6715 or MT8148 was inoculated to Brain Heart Infusion broth (BHI, Difco Laboratories, Detroit Michigan, USA), and subsequently cultivated at $37^{\circ} \mathrm{C}$ for $20 \mathrm{~h}$. The culture broth was centrifuged, and the cells were washed twice with $5 \mathrm{mM}$ phosphate buffered saline (PBS, $\mathrm{pH}$ 7.0) and suspended with PBS. Two milliliters of the suspension was added to $10 \mathrm{~mL}$ of $5 \%$ saccharide (DFA III, sorbitol, palatinose, xylitol, or sucrose) solutions, and the $\mathrm{pH}$ of the solution was measured in due course.

(2) Digestion test. The digestibility of DFA III was evaluated using the digestible enzyme of rat intestine as follows: Physiological saline containing $100 \mathrm{mg}$ rat intestinal acetone powder (Sigma Chemical Company, St. Louis, MO, USA) per $\mathrm{mL}$ was used as the enzyme solution. Maleate buffer ( $25 \mathrm{mM}, \mathrm{pH} 6.0$ ) containing $5 \mathrm{mg}$ test saccharide per $\mathrm{mL}$ and $0.5 \mathrm{~mL}$ enzyme solution per $\mathrm{mL}$ was incubated at $37^{\circ} \mathrm{C}$ for $1 \mathrm{~h}$. This solution was then heated in boiling water for $10 \mathrm{~min}$ to stop the enzyme reaction. Concentrations of fructose and glucose in this solution were determined using commercial kits (fructose; F-kit, Roche Diagnostics K.K., Tokyo, Japan, glucose; GL-5 kainos, Kainos Laboratories Inc., Tokyo, Japan).

The DFA III digestion ratio $(\%)$ is given by $100 \times$ [((fructose in the solution after reaction) - (fructose in the solution before reaction))/(DFA III in the solution before reaction)].

The sucrose digestion ratio $(\%)$ is given by $100 \times 2 \times$ [( glucose in the solution after reaction) - (glucose in the solution before reaction) $) /($ sucrose in the solution be- 
fore reaction)].

(3) Absorption test with everted sacs. The intestinal segments of $40 \mathrm{~cm}$ dissected from the upper portion of the small intestines of rats (7 weeks old) were everted. The 4-cm segments dissected from the everted segments, were ligated with surgical silk at one end. The other end of each sac was ligated immediately after the instillation of $1 \mathrm{~mL}$ of serosal fluid, and the sacs were transferred to individual flasks containing $5 \mathrm{~mL}$ of mucosal fluid. After replacing the air in the flasks with oxygen gas, each flask was incubated for $30 \mathrm{~min}$ at $37^{\circ} \mathrm{C}$ with continuous shaking. The serosal fluid consisted of a $100 \mathrm{mM}$ phosphate buffer (pH 7.4), $120 \mathrm{mM} \mathrm{NaCl}, 3.4 \mathrm{mM} \mathrm{KCl}, 1.2 \mathrm{mM}$ $\mathrm{KH}_{2} \mathrm{PO}_{4}, 1.2 \mathrm{~mm} \mathrm{MgSO}{ }_{4} \cdot 7 \mathrm{H}_{2} \mathrm{O}, 0.6 \mathrm{mM} \mathrm{CaCl}_{2}$. The mucosal fluid consisted of DFA III or sucrose $(5 \mathrm{mM})$ in the serosal fluid. Amount of each saccharide in the mucosal fluids before and after incubation was determined by HPLC.

Absorption coefficient was given by ((total saccharides in the mucosal fluid before incubation) - (total saccharides in the mucosal fluid after incubation). $) /($ incubation time) $\times$ (length of segment)).

(4) In vitro utilization of saccharide by Bifidobacterium. In vitro utilization of DFA III, glucose, and raffinose by Bifidobacterium was evaluated by a method described previously. ${ }^{12)}$ Briefly, a test organism suspension was inoculated into peptone yeast extract Fildes (PYF) broth containing test saccharide at $0.5 \%(\mathrm{w} / \mathrm{v})$. The inoculated media were incubated anaerobically at $37^{\circ} \mathrm{C}$ for $48 \mathrm{~h}$ by the steel wool method. The degree of utilization was determined by the amount of decrease in $\mathrm{pH}$ of the medium. Five strains of Bifidobacterium (B. adolescentis JCM 1275, B. longum JCM 1217, B. breve JCM 1192, B. pseudocatenulatum JCM 1200 and B. catenulatum JCM 1194) were used in this test.

(5) Bacteriological analyses of intestinal and fecal microflora. Bacteriological analyses of the cecal contents in rats or the feces in humans were carried out according to Mitsuoka's method. ${ }^{13)}$ Briefly, the fresh samples were diluted in 10-fold steps with anaerobic phosphate buffer. Each dilution $(0.05 \mathrm{~mL})$ was inoculated onto three nonselective media (BL, EG and TS agar) and eight selective media (BS, ES, NBGT, mLBS, NN, VS, DHL, TATAC agar; the underlined culture media were used only for human feces). Anaerobic incubation was carried out at $37^{\circ} \mathrm{C}$ for $48 \mathrm{~h}$ by the steel wool method, and the aerobic incubation was carried out at $37^{\circ} \mathrm{C}$ for $24-48 \mathrm{~h}$. Identification of the bacterial genus was performed with colonial and cellular morphologies, Gram-stainability, spore formation, and aerobic growth.

(6) Animal experiment. Five-week-old rats with the basal diet for a week as an acclimation period were maintained, and then allocated to three groups ( $n 6$ per group) according to body weight. Each group was fed on the basal diet (Control group) or experimental diets (DFA III or raffinose group) for four weeks. Thereafter, the rats were killed, and the ceca were removed for analysis of microflora, organic acids, and $\mathrm{pH}$ in the contents. The organic acids and $\mathrm{pH}$ were analyzed according to the methods described previously. ${ }^{14)}$

(7) Administration of DFA III to humans. Seven healthy adults, $27 \pm 3$ years old, were served DFA III or raffinose at $5 \mathrm{~g} /$ day for two weeks. The feces were collected twice before administration, during administration of DFA III, during the wash-out period, during administration of raffinose, and after administration, respectively. Each feces sample was immediately subjected to analysis of microflora. Analyses of $\mathrm{pH}$ and water contents of the feces were carried out according to the methods described previously. ${ }^{14)}$ The subjects consumed the normal freechoice diet. None of them were given antibiotic treatment, other therapies, food preparations with live microorganism, other bifidus factors, or fermented soybeans. This study has been conducted in accordance with the Helsinki Declaration of 1975.

Statistical analysis. Results are expressed as mean values along with their standard deviations. In the animal experiment, the significance of differences between groups was evaluated by Scheffe's $F$-test. In the clinical experiment, effect of DFA III on humans was examined by one-way ANOVA followed by Tukey's test for multiple comparisons. The frequency of occurrence of intestinal microbes was statistically analyzed with Fisher's exact probability test.

\section{RESULTS AND DISCUSSION}

Physical, chemical and physiological properties of DFA III were investigated mainly in order to evaluate its usefulness in processed foods. The structure of DFA III crystals is shown in Fig. 1. These crystals had no water molecules. The melting point was $163.7^{\circ} \mathrm{C}$ (authentic; $162^{\circ} \mathrm{C}^{15}$ ). The optical rotation was $+134.5^{\circ}$ (authentic; $\left.+135.64^{\circ}{ }^{15}\right)$. The solubility (Fig. 2(A)) of DFA III was 90-95\% of sucrose. This shows that it is easy to dissolve DFA III. The viscosity of $40 \%(\mathrm{w} / \mathrm{w})$ DFA III solution was lower than that of sucrose below $50^{\circ} \mathrm{C}$ (DFA III, 3.91 $\mathrm{cP}$; sucrose, $4.75 \mathrm{cP}$ at $24^{\circ} \mathrm{C}$ ). However, the viscosity of DFA III was almost equal to that of sucrose below $70^{\circ} \mathrm{C}$ (DFA III, $1.92 \mathrm{cP}$; sucrose, $1.91 \mathrm{cP}$ at $70^{\circ} \mathrm{C}$ ). The hygroscopicity of DFA III was $28-40 \%$ of that of sucrose under a relative humidity of $94 \%$ for 28 days (Fig. 2(B)). Moreover, under a relative humidity of $75 \%$, DFA III did not absorb moisture. This property of DFA III suggests that DFA III is suitable for processed foods, such as dry foods, which don't tolerate moisture. DFA III showed much lower degradability at $100^{\circ} \mathrm{C}$ for $30 \mathrm{~min}$ at $\mathrm{pH} 2$ as compared to sucrose (Fig. 2(C)). DFA III was almost undegraded at $37^{\circ} \mathrm{C}$ and $\mathrm{pH} 3$ after 3 months in comparison with sucrose (no degradation ratio: DFA III 98\%, sucrose $9 \%$ ). Figure 2(D) shows the result of a test conducted on heat coloring in the presence of amino acid. DFA III underwent much less coloring through Maillard reaction than sucrose. The low degradability and Maillard reactivity of DFA III in the low pH solutions suggest that DFA III is a more stable oligosaccharide than sucrose under various conditions. The high stability under acidic conditions suggests that DFA III can be added to acidic beverages, such as fruit juices. DFA III is also suitable for processed foods that don't accept coloring. DFA III has 52\% of the sweetness of sucrose, and its quality of sweetness was similar to that of fructose. In the case of using DFA III as a functional food material (e.g., stimulation of calcium ab- 

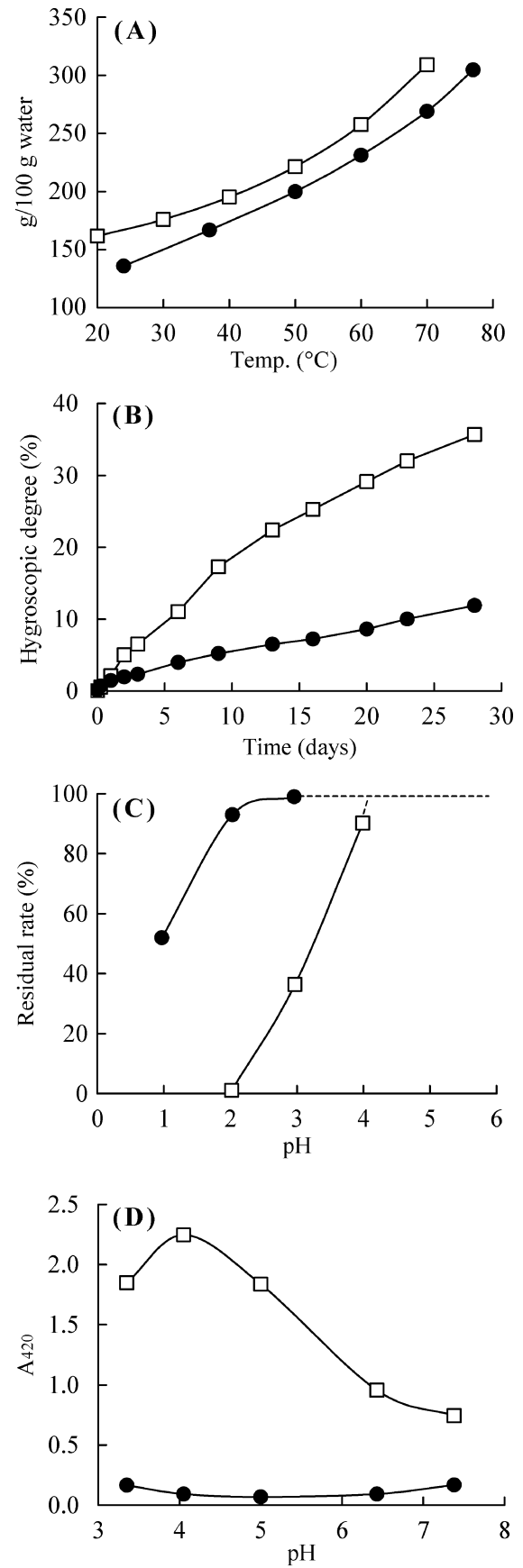

Fig. 2. The physico-chemical properties of DFA III and sucrose.

(A) Solubility, (B) Hygroscopicity, (C) Degradability under acidic and heated conditions, (D) Maillard reactivity. $\bullet$, DFA III; $\square$, sucrose.

sorption), this low sweetness suggests that a sufficient amount of DFA III can be added to functional foods, such as supplements, without changing the taste as compared with sucrose.

The results of the cariogenic test with Streptococcus mutans MT8148 is given in Fig. 3. S. mutans MT8148 did not produce acid from DFA III. The same result was obtained with $S$. mutans 6715 . These results show that the cariogenicity of DFA III is low. In comparison to sucrose, DFA III was not degraded by the digestible enzyme of rat intestine in vitro (digestion ratio: DFA III below $2 \%$, sucrose $64 \%$ ). The absorption ratio of DFA III was below $2.0 \mu \mathrm{g} / \mathrm{cm} \cdot \min$ and was much lower than that of sucrose, $14.2 \pm 2.1 \mu \mathrm{g} / \mathrm{cm} \cdot \mathrm{min}$. These results show that DFA III

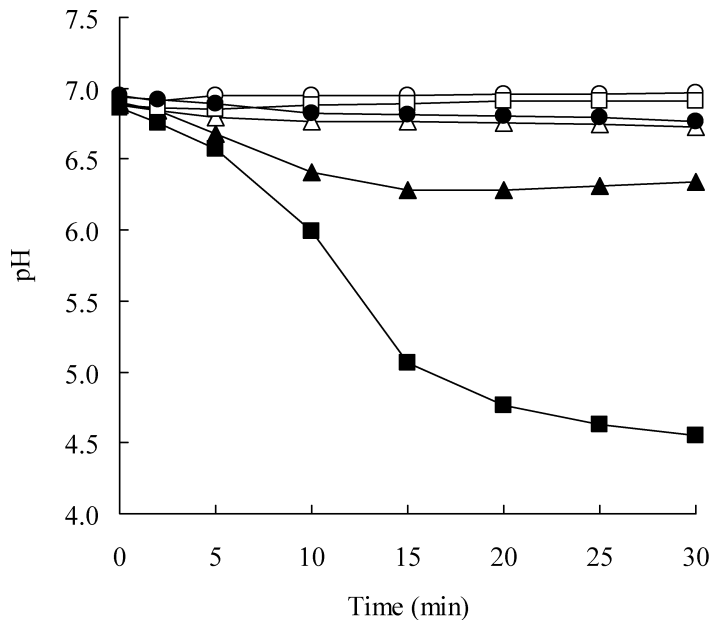

Fig. 3. The acid production from saccharides by Streptococcus mutans MT8418.

The suspension of Streptococcus mutans with PBS was added to $5 \%$ saccharide aqueous solution, and the $\mathrm{pH}$ of the solution was measured over the time course. $\bigcirc$, blank; $\bullet$, DFA III; $\triangle$, sorbitol; $\mathbf{\wedge}$, palatinose; $\square$, xylitol; $\mathbf{\square}$, sucrose.

is an indigestible oligosaccharide, similar to many other oligosaccharides. ${ }^{5)}$ Glucose and raffinose were utilized by all strains of tested Bifidobacterium (B. adolescentis, B. longum, B. breve, B. pseudocatenulatum and B. catenulatum). The difference in $\mathrm{pH}$ between the test and control groups was larger than one. However, DFA III was not utilized by the Bifidobacterium. The difference in $\mathrm{pH}$ between the test and control was smaller than 0.5.

Basal or oligosaccharide diets containing DFA III or raffinose were fed to the rats for four weeks. No statistical differences were observed in terms of body weight gain $(p$ $=0.64)$, feed intake $(p=0.51)$ or feed efficiency $(p=$ 0.80 ) between the control and oligosaccharide groups (Table 1), and no case of diarrhea were observed in any rats. The weights and the $\mathrm{pHs}$ of the cecal contents, and the amount of the cecal organic acids are also shown in Table 1 . The weights of the cecal contents of the oligosaccharide groups were significantly increased, and their $\mathrm{pHs}$ were significantly decreased as compared with that of the control group. The amount of cecal organic acids of the oligosaccharide groups increased remarkably compared with that of the control group. In particular, the DFA III group showed a higher proportion of acetic acid (acetic acid: propionic acid: butyric acid $=13: 2: 1 \mathrm{vs}$. control group, $7: 2: 1$, raffinose group, $9: 2: 1$ ). These results indicate the possibility that DFA III has a fermentative property because of the presence of intestinal bacteria of rats. The counts of Bacteroidaceae, Enterobacteriaceae and Streptococaceae in the ceca of the oligosaccharide groups significantly decreased in comparison with that of the control group (Table 2). The increase in the number of facultative aerobes, such as Enterobacteriaceae and Streptococaceae, is reported as a feature of the abnormal flora that is observed in immunodeficiency, surgical operation, aging, etc. ${ }^{16)}$ It is expected that DFA III and raffinose contribute to the prevention of the abnormal flora. Raffinose diets induce a significant increase in the number of Bifidobacterium in rats; however, DFA III diets do not affect the Bifidobacterium count. This result is in agreement with in vitro carbohydrate utilization tests performed us- 
Table 1. Effect of oligosaccharides on the body weight gain, feed intake, cecal content weight, cecal $\mathrm{pH}$ and cecal organic acids in rats.

\begin{tabular}{lccc}
\hline & Control $^{*}$ & DFA III** & Raffinose $^{* * *}$ \\
\hline Initial body weight $(\mathrm{g})$ & $181 \pm 4$ & $181 \pm 4$ & $181 \pm 4$ \\
Body weight gain $(\mathrm{g})$ & $147 \pm 13$ & $138 \pm 24$ & $142 \pm 7$ \\
Feed intake (g/rat) & $516 \pm 27$ & $502 \pm 14$ & $507 \pm 18$ \\
Feed efficiency & $0.28 \pm 0.02$ & $0.27 \pm 0.04$ & $0.28 \pm 0.01$ \\
\hline Cecal contents $(\mathrm{g})$ & $2.2 \pm 0.2^{\mathrm{c}}$ & $4.0 \pm 0.5^{\mathrm{b}}$ & $6.0 \pm 0.6^{\mathrm{a}}$ \\
pH of cecal contents & $7.0 \pm 0.1^{\mathrm{a}}$ & $6.4 \pm 0.3^{\mathrm{b}}$ & $5.9 \pm 0.4^{\mathrm{b}}$ \\
\hline Cecal organic acids & $234.1 \pm 35.1^{\mathrm{c}}$ & $496.5 \pm 71.6^{\mathrm{b}}$ & $811.0 \pm 59.2^{\mathrm{a}}$ \\
$\quad(\mu$ mol/cecum) & & \\
Acetic acid & $150.7 \pm 22.5^{\mathrm{c}}$ & $360.5 \pm 56.9^{\mathrm{b}}$ & $506.4 \pm 100.5^{\mathrm{a}}$ \\
Propionic acid & $41.7 \pm 5.8^{\mathrm{b}}$ & $58.7 \pm 11.7^{\mathrm{b}}$ & $88.4 \pm 24.2^{\mathrm{a}}$ \\
$n$-Butyric acid & $22.6 \pm 4.3^{\mathrm{b}}$ & $28.3 \pm 7.4^{\mathrm{b}}$ & $56.6 \pm 20.0^{\mathrm{a}}$ \\
Formalic acid & $0.8 \pm 0.1^{\mathrm{b}}$ & $1.3 \pm 0.5^{\mathrm{b}}$ & $5.6 \pm 3.5^{\mathrm{a}}$ \\
$n$-Valeric acid & $4.8 \pm 1.0$ & $5.3 \pm 3.2$ & $1.7 \pm 1.1$ \\
$i$-Valeric acid & $3.3 \pm 0.6$ & $2.7 \pm 2.3$ & $6.4 \pm 3.2$ \\
Succinic acid & $9.7 \pm 4.2^{\mathrm{b}}$ & $33.5 \pm 29.1^{\mathrm{ab}}$ & $50.1 \pm 31.3^{\mathrm{a}}$ \\
Lactic acid & $0.6 \pm 0.5$ & $6.1 \pm 4.6$ & $95.7 \pm 137.2$ \\
\hline
\end{tabular}

${ }^{*}$ Control group fed the basal purified diet. ${ }^{*}$ DFA III group fed the basal purified diet containing DFA III at $2 \%$ level. ${ }^{* * *}$ Raffinose group fed the basal purified diet containing raffinose at $5 \%$ level. Values are expressed as mean \pm SD. Means not sharing a common superscript letter are significantly different $(p<0.05)$. ing Bifidobacterium. The DFA III diet increased Clostridium in the ceca, although the species of Clostridium spp. has not yet been identified. Though this genus contains harmful species of bacteria such as Clostridium perfringens, it has been reported that indigenous Clostridium spp. inhibit intestinal colonization of exogenous pathogens such as Clostridium difficile ${ }^{17)}$ and Escherichia coli. ${ }^{18)}$

In healthy humans, daily intake of $5 \mathrm{~g}$ DFA III caused no diarrhea and no change in the fecal microflora (Table 3). These results were different from the ones observed in the rats. Raffinose also did not caused any diarrhea, but raffinose intake induced a significant increase in Bifidobacteria compared with the period before administration. There were no changes in the fecal $\mathrm{pH}$ or the fecal water contents with or without intake of each oligosaccharide (range of average values across all test periods: $\mathrm{pH}$ 6.1-6.3, water content 77.0-80.0\%). Though no change of $\mathrm{pH}$ in the feces from volunteers given DFA III was observed in this study, it was suggested that DFA III is fermented in large intestines of humans too because DFA III was fermented in vitro by the human feces like raffinose (our data unpublished). The usual bacteriological

Table 2. Effect of oligosaccharides on the cecal flora in rats.

\begin{tabular}{|c|c|c|c|c|c|c|}
\hline & \multicolumn{2}{|c|}{ Control $^{* 1}$} & \multicolumn{2}{|c|}{ DFA III $^{* 2}$} & \multicolumn{2}{|c|}{ Raffinose $^{* 3}$} \\
\hline Total bacteria & $10.0 \pm 0.1^{* 4, \mathrm{~b}}$ & & $10.1 \pm 0.0^{b}$ & & $10.3 \pm 0.1^{\mathrm{a}}$ & \\
\hline Bacteroidaceae & $\begin{array}{r}10.0 \pm 0.1^{\mathrm{a}} \\
95 \pm 5^{* 6, \mathrm{a}}\end{array}$ & $(100)^{* 5}$ & $\begin{array}{c}9.6 \pm 0.2^{\mathrm{b}} \\
42 \pm 18^{\mathrm{b}}\end{array}$ & (100) & $\begin{array}{c}9.5 \pm 0.2^{b} \\
21 \pm 10^{c}\end{array}$ & (100) \\
\hline Bifidobacterium & $\begin{array}{r}7.3 \pm 1.0^{\mathrm{b}} \\
1 \pm 1^{* 6, \mathrm{~b}}\end{array}$ & (50) & $\begin{array}{c}8.3 \pm 0.0^{\mathrm{b}} \\
1 \pm 1^{\mathrm{b}}\end{array}$ & (67) & $\begin{array}{c}9.7 \pm 0.6^{\mathrm{a}} \\
45 \pm 30^{\mathrm{a}}\end{array}$ & $(100)$ \\
\hline Eubacterium & $\begin{aligned} 7.9 & \pm 0.3 \\
0 & \pm 0^{* 6}\end{aligned}$ & (50) & $\begin{array}{c}8.0 \pm 1.2 \\
2 \pm 2\end{array}$ & (67) & $\begin{array}{c}8.4 \pm 0.1 \\
1 \pm 1\end{array}$ & (83) \\
\hline Peptococaceae & $\begin{array}{r}8.2 \pm 0.6 \\
3 \pm 5^{* 6}\end{array}$ & (83) & $\begin{array}{c}8.5 \pm 0.7 \\
5 \pm 6\end{array}$ & (83) & $\begin{array}{c}9.2 \pm 0.6 \\
16 \pm 15\end{array}$ & (100) \\
\hline Clostridium & $\begin{array}{r}8.0 \pm 0.5^{\mathrm{b}} \\
0 \pm 1^{* 6, \mathrm{~b}}\end{array}$ & $(33)^{\mathrm{b}}$ & $\begin{array}{l}9.7 \pm 0.2^{\mathrm{a}} \\
47 \pm 17^{\mathrm{a}}\end{array}$ & $(100)^{\mathrm{a}}$ & $\begin{array}{l}9.1 \pm 0.7^{\mathrm{ab}} \\
13 \pm 10^{\mathrm{b}}\end{array}$ & $(100)^{\mathrm{a}}$ \\
\hline $\begin{array}{l}\text { Lactobacillus } \\
\text { Total aerobes }\end{array}$ & $\begin{array}{l}6.7 \pm 0.7 \\
7.5 \pm 0.4^{\mathrm{a}}\end{array}$ & (100) & $\begin{array}{l}7.6 \pm 1.3 \\
6.6 \pm 0.3^{b}\end{array}$ & (100) & $\begin{array}{l}8.5 \pm 0.7 \\
6.5 \pm 0.5^{b}\end{array}$ & (100) \\
\hline Enterobacteriaceae & $7.3 \pm 0.3^{\mathrm{a}}$ & (100) & $6.2 \pm 0.6^{b}$ & (100) & $6.2 \pm 0.8^{\mathrm{b}}$ & (100) \\
\hline Streptococaceae & $6.9 \pm 0.6^{\mathrm{a}}$ & $(100)$ & $6.3 \pm 0.2^{\mathrm{b}}$ & $(100)$ & $6.1 \pm 0.2^{\mathrm{b}}$ & $(100)$ \\
\hline
\end{tabular}

Table 3. Effect of oligosaccharides on human fecal flora.

\begin{tabular}{|c|c|c|c|c|c|c|c|c|c|c|}
\hline \multirow{3}{*}{ Total bacteria } & \multicolumn{10}{|c|}{ Schedule of administration } \\
\hline & \multicolumn{2}{|l|}{ Before } & \multicolumn{2}{|c|}{ DFA III ${ }^{* 1}$} & \multicolumn{2}{|c|}{ Wash-out period } & \multicolumn{2}{|c|}{ Raffinose $^{* 1}$} & \multicolumn{2}{|c|}{ After } \\
\hline & $10.6 \pm 0.2^{* 2}$ & & $10.5 \pm 0.4$ & & $10.6 \pm 0.4$ & & $10.7 \pm 0.2$ & & $10.6 \pm 0.2$ & \\
\hline Bacteroidaceae & $\begin{array}{c}10.3 \pm 0.3 \\
50 \pm 15^{* 4}\end{array}$ & $(100)^{* 3}$ & $\begin{array}{c}10.1 \pm 0.5 \\
47 \pm 17\end{array}$ & $(100)$ & $\begin{array}{c}10.3 \pm 0.4 \\
54 \pm 13\end{array}$ & (100) & $\begin{array}{c}10.3 \pm 0.3 \\
40 \pm 15\end{array}$ & (100) & $\begin{array}{c}10.3 \pm 0.2 \\
50 \pm 14\end{array}$ & $(100)$ \\
\hline Bifidobacterium & $\begin{array}{l}9.8 \pm 0.3^{\mathrm{b}} \\
16 \pm 11^{* 4, \mathrm{~b}}\end{array}$ & (100) & $\begin{array}{c}9.8 \pm 0.3^{\mathrm{ab}} \\
24 \pm 16^{\mathrm{ab}}\end{array}$ & (100) & $\begin{array}{c}9.8 \pm 0.3^{\mathrm{ab}} \\
19 \pm 12^{\mathrm{b}}\end{array}$ & $(100)$ & $\begin{array}{r}10.1 \pm 0.3^{\mathrm{a}} \\
35 \pm 19^{\mathrm{a}}\end{array}$ & (100) & $\begin{array}{c}9.9 \pm 0.3^{\mathrm{ab}} \\
20 \pm 11^{\mathrm{ab}}\end{array}$ & $(100)$ \\
\hline Eubacterium & $9.8 \pm 0.4$ & (100) & $9.5 \pm 0.5$ & (100) & $9.7 \pm 0.5$ & (100) & $9.8 \pm 0.5$ & $(100)$ & $9.8 \pm 0.2$ & (100) \\
\hline Peptococaceae & $9.6 \pm 0.6$ & (100) & $9.2 \pm 0.8$ & (100) & $9.6 \pm 0.3$ & (93) & $9.4 \pm 0.4$ & (100) & $9.5 \pm 0.5$ & (100) \\
\hline Clostridium perfringens & $4.7 \pm 1.7$ & $(57)$ & $4.5 \pm 1.3$ & $(50)$ & $5.6 \pm 1.4$ & (57) & $4.3 \pm 1.7$ & $(43)$ & $3.9 \pm 1.7$ & (79) \\
\hline Clostridium-others & $8.8 \pm 0.5$ & (64) & $8.1 \pm 1.1$ & (43) & $8.3 \pm 1.3$ & (43) & $8.8 \pm 0.6$ & (29) & $8.4 \pm 1.1$ & (43) \\
\hline Veillonella & $6.0 \pm 0.8$ & (71) & $5.9 \pm 1.4$ & (71) & $6.3 \pm 1.5$ & (71) & $6.6 \pm 1.4$ & (71) & $6.5 \pm 1.3$ & (64) \\
\hline Lactobacillus & $5.6 \pm 1.3$ & (86) & $5.5 \pm 1.5$ & (86) & $5.4 \pm 1.6$ & (86) & $6.0 \pm 1.7$ & (100) & $5.8 \pm 1.7$ & (93) \\
\hline Curved rods & $10.0 \pm 0.0$ & (14) & $10.1 \pm 0.2$ & (14) & $9.8 \pm 0.3$ & (14) & $9.6 \pm 0.0$ & (14) & $9.9 \pm 0.4$ & (14) \\
\hline Total aerobes & $7.6 \pm 0.6$ & & $7.3 \pm 0.5$ & & $7.8 \pm 0.7$ & & $7.8 \pm 0.7$ & & $8.0 \pm 0.7$ & \\
\hline Enterobacteriaceae & $7.0 \pm 1.0^{\mathrm{ab}}$ & (100) & $6.9 \pm 0.5^{\mathrm{b}}$ & (100) & $7.5 \pm 0.6^{\mathrm{ab}}$ & (100) & $7.5 \pm 0.8^{\mathrm{ab}}$ & $(100)$ & $7.8 \pm 0.7^{\mathrm{a}}$ & (100) \\
\hline Streptococcus & $6.3 \pm 1.5$ & $(100)$ & $6.7 \pm 0.9$ & (100) & $6.9 \pm 1.1$ & $(100)$ & $6.7 \pm 1.2$ & $(100)$ & $7.0 \pm 1.3$ & $(100)$ \\
\hline
\end{tabular}

${ }^{* 1}$ Administration of oligosaccharides at $5 \mathrm{~g}$ per day. ${ }^{* 2}$ Values are expressed as mean \pm SD of bacterial counts $\left(\log\right.$ NO. $/ \mathrm{g}$ wet stool). ${ }^{* 3} \mathrm{Fre}-$ quency of occurrence. ${ }^{*}$ Values are expressed as mean \pm SD of percentage of each bacteria group to total counts. Means not sharing a common superscript letter are significantly different $(p<0.05)$. 
analysis technique that we have used may be not be able to completely analyze the change in intestinal microflora. Therefore, the identification with biogenetic techniques that detect the targeted genes for identification at species level are required in order to analyze change of intestinal microflora in detail.

An interesting characteristic is that calcium absorption in rats that were fed with DFA III was found to be stimulated not only in the large intestine but also in the small intestine. ${ }^{8)}$ However, this calcium absorption is stimulated only in the large intestine when other oligosaccharides were fed. ${ }^{6,7)}$ In the commercialization as a new food material, DFA III is greatly expected to be useful for human health. We have also progressed in the technology for producing DFA III on an industrial scale. In future, we expect that the useful functions of DFA III such as stimulation of calcium absorption will be explained in humans too.

\section{REFERENCES}

1 ) K. Tanaka, T. Uchiyama and A. Ito: Formation of di-D-fructofuranose $1,2^{\prime}: 2,3^{\prime}$ dianhydride from inulin by an extracellular inulase of Arthrobacter ureafaciens. Biochem. Biophys. Acta, 284, 248-256 (1972).

2 ) K. Haraguchi, M. Kishimoto, K. Seki, K. Hayashi, S. Kobayashi and K. Kainuma: Purification and properties of inulin fructotransferase (depolymerizing) from Arthrobacter globiformis C11-1. Agric. Biol. Chem., 52, 291-292 (1988).

3 ) M. Kawamura, S. Takahashi and T. Uchiyama: Purification and some properties of inulin fructotransferase (depolymerizing) from Arthrobacter ilicis. Agric. Biol. Chem., 52, 32093210 (1988).

4 ) A. Yokota, S. Hirayama, K. Enomoto, Y. Miura, S. Takao and F. Tomita: Production of inulin fructotransferase (depolymerizing) by Arthrobacter sp. H65-7 and preparation of DFA III from inulin by the enzyme. J. Ferment. Bioeng., 72, 258-261 (1991).

5 ) J. Van Loo, J. Cummings, N. Delzenne, H. Englyst, A. Franck, M. Hopkins, N. Kok, G. Macfarlane, D. Newton, M. Quigley, M. Roberfroid, T. van Vliet and E. van den Heuvel: Functional food properties of non-digestible oligosaccharides: A consensus report from the ENDO project (DGXII AIRII-CT 94-1095). Br. J. Nutr., 81, 121-132 (1999).

6 ) O. Chonan and M. Watanuki: Effect of galactooligosaccharides on calcium absorption on rats. J. Nutr. Sci. Vitaminol ., 41, 95104 (1995)

7 ) A. Ohta, N. Osakabe, K. Yamada, Y. Saito and H. Hidaka: Effects of fructooligosaccharides and other saccharides on $\mathrm{Ca}$, $\mathrm{Mg}$ and $\mathrm{P}$ absorption in rats. J. Jpn. Soc. Nutr. Food Sci., 46, 123-129 (1993) (in Japanese).

8 ) T. Suzuki, H. Hara, T. Kasai and F. Tomita: Effects of difructose anhydride III on calcium absorption in small and large intestines of rats. Biosci. Biotechnol. Biochem., 62, 837-841 (1998).

9 ) H. Mineo, H. Hara, H. Kikuchi, H. Sakurai and F. Tomita: Various indigestible saccharides enhance net calcium transport from the epithelium of the small and large intestine of rats in vitro. J. Nutr., 131, 3243-3246 (2001).

10) K. Ebihara, Y. Imamura and S. Kiriyama: Effect of dietary mineral composition on nutritional equivalency of amino acid mixtures and casein in rats. J. Nutr., 109, 2106-2116 (1979).

11) American Institute of Nutrition: Report of the American Institute of Nutrition ad hoc Committee on standards for nutritional studies. J. Nutr., 107, 1340-1348 (1977).

12) T. Mitsuoka: A Color Atlas of Anaerobic Bacteria. Sobunsha, Tokyo (1980) (in Japanese).

13) T. Mitsuoka, T. Sega and S. Yamamoto: Eine verbesserte methodik der qualitativen und qunatitativen analyse der darmflora von menschen und tieren. Zbl. Bakt. Hyg., I. Abt. Orig., 195,
455-469 (1965).

14) T. Nagura, T. Nakamura, T. Kishida, T. Aritsuka, K. Sayama and Y. Benno: Effect of beet dietary fiber on intestinal microflora in humans and rats. J. Intest. Microbiol., 11, 109-115 (1998) (in Japanese).

15) R.F. Jackson and E. McDonald: Two new crystalline difructose anhydrides from hydrolyzed inulin. Bur. Stand. J. Res., 6, 709-715 (1931).

16) T. Mitsuoka: Taxonomy and ecology of bifidobacteria. Bifidobacteria Microflora, 3 (1), 11-28 (1984).

17) K. Itoh, W.K. Lee, H. Kawamura, T. Mitsuoka and T. Magaribuchi: Intestinal bacteria antagonistic to Clostridium difficile in mice. Lab. Anim., 21, 20-25 (1987).

18) K. Itoh and R. Freter: Control of Escherichia coli populations by a combination of indigenous clostridia and lactobacilli in gnotobiotic mice and continuous-flow cultures. Infect. Immun., 57, 559-565 (1989).

\section{酵素反応によってイヌリンより生産された ジフルクトース-アンヒドリド IIIの物理的, 化学的および生理学的性質}

菊地裕人 ${ }^{1}$, 名倉泰三 ${ }^{1}$, 井上政尚 ${ }^{1, *}$, 岸田太郎 ${ }^{1, * *}$

櫻井博章 ${ }^{1}$, 横田 篤 ${ }^{2}$, 浅野行蔵 ${ }^{2}$, 冨田房男 ${ }^{2}$ 佐山晃司 ${ }^{1}$, 仙波美博 ${ }^{1}$

${ }^{1}$ 日本甜菜製糖株式会社総合研究所

(080-0831 帯広市稲田町南 9 線西 13 番地)

2 北海道大学大学院農学研究科応用生命科学科

（060-8589 札幌市北区北 9 条西 9丁目）

*現所属：日本甜菜製糖株式会社芽室製糖所

（082-0005 芽室市東芽室基線 26 番地）

**現所属：愛媛大学農学部生物資源学科

（790-8566 松山市樽味 3-5-7）

我々が，チコリー由来のイヌリンより製造した高純度 difructose anhydride III (DFA III; $\alpha$-D-fructofuranose- $\beta$-Dfructofuranose 1,2' : 2,3' dianhydride) 結晶の加工食品にお ける有用性を評価するために，物理的，化学的および生 理学的性質を調査した. DFA III は水への溶解性が高く, スクロースの 90-95\%の溶解度を示した。 また, DFA III の吸湿性はスクロースよりも低く，低 $\mathrm{pH}$ における DFA III の分解性およびメイラード反応性は, スクロースより もかなり低いことが明らかとなった。 DFAIII はin vitroに おいて Streptococcus mutans MT8148 株および 6715 株に資 化されず，低う蝕性であることが示唆された。またDFA III in vitroにおいてラット消化酵素によって分解され ず，ラット小腸を用いた反転腸管サック法においても吸 収は認められなかった。これらの結果はDFAIIIが他の多 くのオリゴ糖同様に非消化性のオリゴ糖であることを示 している。一方, DFA IIIを摂取したラットの盲腸では, 短鎖脂肪酸の増大と菌叢の変化が認められたものの, Bifidobacterium の増加は認められなかった。 1 日にDFA III $5 \mathrm{~g}$ を 2 週間摂取したヒトでは, 粪便菌叢の変化は認められ なかった。 